
Board of Governors of the Federal Reserve System
International Finance Discussion Papers
Number 1088
August 2013

\title{
"Fool Me Once..." \\ Did U.S. Investors Play it Safer in the European Debt Crisis?
}

Carol C. Bertaut, Fang Cai, Nyssa Kim

NOTE: International Finance Discussion Papers are preliminary materials circulated to stimulate discussion and critical comment. References to International Finance Discussion Papers (other than an acknowledgment that the writer has had access to unpublished material) should be cleared with the author or authors. Recent IFDPs are available on the Web at www.federalreserve.gov/pubs/ifdp/. This paper can be downloaded without charge from the Social Science Research Network electronic library at wWw.ssrn.com. 


\title{
"Fool Me Once..." Did U.S. Investors Play it Safer in the European Debt Crisis?
}

\author{
Carol Bertaut, Fang Cai, and Nyssa Kim*
}

\begin{abstract}
This paper examines U.S. investors' portfolio investment patterns since the global financial crisis, particularly since the European debt crisis that began in late 2009. The global financial crisis during 2007-2009 was accompanied by an increase in U.S. investors' home bias. U.S. investors experienced significant valuation losses and pulled back notably from their foreign investment, especially from foreign debt. In contrast, while they have also incurred sizable losses on cross-border investment during the European debt crisis, U.S. investors so far have not shown any increase in home bias, and they have not even pulled back from their long-term investments in Europe. Holdings data show that U.S. investors have continued to invest in European securities, particularly in government debt, but have made little new investment in the financial sector. This continued interest in European securities could owe to the fact that most of U.S. holdings of European debt have been concentrated in dollar-denominated debt issued by core euro area countries and the United Kingdom, which are deemed relatively safe. Changes in the composition of holdings over the past couple years suggest that U.S. investors have behaved in a way that reflects their diversity and differing objectives: while investors reached for higher yields in government debt, there also appears to be some shift toward safer investment in the financial sector.
\end{abstract}

Keywords: cross-border investment, financial crisis, portfolio allocation, home bias JEL classifications: F3, G1

\footnotetext{
* We thank Steven Kamin, Mark Carey, Jaime Marquez, Charlie Thomas, Hong Zhang and participants at the International Finance conference at the Federal Reserve Board, the International Conference on the Global Financial Crisis at University of Southampton, and the 2013 China International Conference in Finance for helpful comments. We thank Clara Vega, Juan-Miguel Londono-Yarce, and Michael Zdinak for providing some data. Hugh Montag provided excellent research assistance. The views in this paper are solely the responsibility of the authors and should not be interpreted as reflecting the view of the Board of Governors of the Federal Reserve System or of any other person associated with the Federal Reserve System. Corresponding author: Fang Cai, Fang.Cai@frb.gov
} 


\section{Introduction}

The global financial crisis that began in the summer of 2007 and erupted in full force in the fall of 2008 had a profound effect on US investor portfolios. According to U.S. Flow of Funds statistics, total U.S. holdings of securities - credit market instruments, equity, and mutual fund shares - fell by nearly \$13 trillion between fall 2007 and spring 2009, a loss of more than

20 percent over the 18-month period. As global investors lost faith in the value of mortgage- and other asset-backed securities (ABS) and other structured products that purported to transform subprime housing loans into AAA rated securities, they tried to unwind these and other more risky investment positions for the safety of home investments in safe and liquid assets. This tendency to leave foreign markets for home during financial crises has recently been documented in a growing literature on capital retrenchment (Milesi-Ferretti and Tille (2011), Forbes and Warnock (2011) and Fratzscher (2011)).

In this paper, we contrast the behavior of U.S. investors during the global financial crisis with their response to the ongoing euro-area crisis, which began to emerge in late 2009. Our study attempts to address two questions : First, having been "fooled once” by the promise of higher returns for only slightly increased risk in the ABS market during the global financial crisis, have U.S. investors become cautious during the European debt crisis and scaled back their investment in foreign securities? Second, in particular, how have U.S. investors adjusted their holdings of European securities? Have they pulled back or do they continue to have large exposures that could prove equally risky should European financial markets become even more unsettled? With these questions, we provide new evidence on how U.S. investors are managing their international portfolios during a period of great uncertainty and very low risk-free interest rates. 
Since the pioneering work of French and Poterba (1991), it has been well known that investors exhibit a home bias in their international portfolio investment, i.e., they tend to hold too little of their financial wealth in foreign assets when compared with the benchmark of standard portfolio theory. ${ }^{1}$ Traditional portfolio choice theories frame the home bias as a function of the benefits of holding foreign foreign assets less the costs (Cooper and Kaplanis (1994)). Alternative approaches explain home bias by examining portfolio choice under uncertainty (Uppal and Wang (2003)), information asymmetry (Brennan and Cao (1997), Ahearne, Griever, and Warnock (2004), and Choe, Kho, and Stulz (2005)), or familiarity bias (Huberman (2001) and Cao et al (2011)).

Home bias during financial crises has received increasing attention among researchers in recent years. All else equal, theories of portfolio choice under uncertainty predict that an increase in uncertainty, information asymmetry, or heightening of familiarity bias during crisis periods would lead investors to reduce their foreign portfolio share and thus increase their home bias. Among empirical studies using capital flows and transactions data, Milesi-Ferretti and Tille (2011) suggests that the capital retrenchment during the global financial crisis led to an increase in portfolio home bias. By examining U.S. investors' responses during the European debt crisis in comparison to the global financial crisis, our paper sheds new light on changes in U.S. investors' home bias during crisis periods. Our study also touches on a potential vulnerability for Europe. As is the case for many developed economies, the European financial system has huge claims on foreigners and huge liabilities to foreign investors. Should the crisis spark an international retreat from European investments, the region's troubles would be compounded.

\footnotetext{
${ }^{1}$ For detailed reviews of the home bias literature, see Lewis (2011) and Karolyi and Stulz (2003).
} 
Using comprehensive, security-level data on U.S. cross-border holdings to analyze changes in investment in European securities, we find that in contrast to the increased home bias during the global financial crisis, U.S. investors have not pulled back from cross-border exposure, even to euro area debt securities, since the start of the euro crisis. In fact, U.S. investors have continued to invest in European debt, particularly in government debt, but have made little new investment in the financial sector. In part, this relative stability reflects that most of the US investor European bond portfolio is invested in fairly safe, dollar-denominated debt issued by core euro area countries and the United Kingdom. U.S. investor exposure to euro area periphery debt was small to begin with, and remains a small share of the U.S. portfolio. However, U.S. investors have made some adjustments to their portfolio of European securities on the margin: while investors "reached for yield" in government debt, increasing allocations to Eastern European debt and even to peripheral euro area government debt, especially in 2011, we also see some shifts into safer, more highly rated securities in the financial sector.

The paper proceeds as follows. Section 1 provides a background review of changes of U.S. investor portfolios during the global financial crisis. Section 2 describes data used and basic statistics of U.S. investment portfolios abroad. Section 3 examines patterns of U.S. holdings and net investment flows into Europe, and how they have changed since the onset of the European crisis. Section 4 presents detailed evidence of U.S. investors' responses to European government debt and financial debt. Section 5 concludes.

\section{U.S. Investor Portfolios and the Global Financial Crisis}

Defining characteristics of the U.S. financial landscape leading up to the financial crisis include the rapid growth of the shadow banking system and the associated expansion of 
alternative credit instruments, including asset-backed commercial paper (ABCP), ABS, and other structured products. The causes and consequences of this buildup have been examined extensively by policy makers and researchers. For example, Gorton $(2008,2009)$ and Coval, Jurek, and Stafford (2008) describe the process by which loans, some of which were of dubious quality, were transformed into highly rated structured investment products. Gerardi, Lehnert, Sherlund, and Willen, (2008) and Demyanyk and van Hemert (2009) document how the period of prolonged house price appreciation prior to the crisis helped to hold down subprime delinquencies, allowing ABS to develop a record of dependability and an illusion of safety. Bernanke et al. (2011) and Bertaut et al. (2012) discuss the interplay of capital inflows from foreign official investors (almost exclusively into Treasuries and agencies) and European investors (primarily into ABS and other financial debt securities) in contributing to the buildup of vulnerabilities preceding the crisis: as official investors absorbed roughly 80 percent of the increase in the stock of Treasuries and agencies between 2003 and 2007, other investors (domestic and foreign) were likely crowded out of the market for conventional safe and liquid securities and enticed by highly rated alternatives offering slightly better yields. Tarullo (2012) discusses other sources of the demand for "safe" and liquid assets in the years before the crisis.

The buildup in what turned out ex post to be risky asset positions and the collapse in U.S. investor wealth during the financial crisis is apparent from U.S. Flow of Funds statistics. As shown in Table 1, the value of U.S. securities rose $\$ 20.5$ trillion from end-2003 to mid-2007, and then declined by nearly $\$ 12$ trillion over the next 21 months, largely from losses in equity and mutual fund shares as financial markets tumbled. But the rise and subsequent decline in financial sector debt securities including ABCP, ABS, and other structured investment instruments, is also noteworthy. After increasing only $\$ 700$ billion between end-2000 and end- 
2003, ABCP and “private label” ABS outstanding more than doubled to reach $\$ 4.5$ trillion over the next $3 \frac{1}{2}$ years. And in contrast to continued growth in other corporate debt securities during the crisis, holdings of ABCP and ABS decreased by $\$ 575$ billion, a loss of nearly 13 percent, while holdings of all other financial debt barely increased.

Although losses directly related to ABS were presumably felt most by these the biggest holders of these securities, overall wealth declines related to the financial crisis were much larger and more widespread. In particular, total U.S. losses on the cross-border portion alone are estimated at \$2.7 trillion between Q2 of 2007 and Q1 of 2009, reflecting the role of the U.S. as the "global insurer" by investing abroad primarily in risky assets such as equity which lost value during the crisis while external liabilities were primarily in safe long-term debt securities, including U.S. Treasury securities, which gained in value (Gourinchas, Rey, and Truempler, 2012).

We next turn to developments in U.S. investor holdings of foreign securities - especially European securities - since the onset of the European debt crisis to explore whether this "risktaking global investor” nature still holds true and how their home bias has changed.

\section{Data and Basic Statistics}

\subsection{Data}

Our data are from the annual Treasury International Capital (TIC) data on U.S. crossborder portfolio holdings. These data are at the security level and measure holdings by all U.S. resident investors of securities issued by foreigners. They offer annual snapshots of what U.S. investors are holding of foreign equity and long-term and short-term debt securities as of December 31 each year. Long-term securities are defined as having an original maturity one 
year or above. The respondents to the survey are banks, broker-dealers, hedge funds, insurance companies, mutual funds, non-financial corporations, and pension funds who reside in the United States, although most data are collected from U.S. custodians who report on behalf of their U.S. investor clients. ${ }^{2}$ Our analysis covers the years from 2007 to 2011.

The TIC data are collected on a balance-of-payments basis, which are designed to measure a country's cross-border financing needs. Specifically, the TIC data focus on residency — for U.S. investment abroad, they include only securities issued by foreign residents, and only those held by U.S. resident investors. As such, our data are consistent with measures of the International Investment Position and with the Flow of Funds definition of the "Rest of the World” sector, but differ from measures of country exposure, which typically focus on the nationality of the issuer's parent. ${ }^{3}$

\subsection{Basic Statistics}

As shown in Figure 1, private portfolio holdings - equity and long-term and short-term debt securities - account for much of U.S. holdings foreign financial assets. ${ }^{4}$ In 2011, private portfolio holdings are about three fourths of total U.S. holdings of foreign financial assets, with equity taking about half share and long-term debt securities accounting for 22 percent. Short-

\footnotetext{
${ }^{2}$ All U.S. resident custodians and end-investors with holdings of foreign portfolio securities above the reporting threshold (total holdings of $\$ 100$ million or above as of reporting date) are required to report by law.

${ }^{3}$ Thus, a purchase by a U.S. resident of corporate bond issued by a French firm's subsidiary in the United States increases our exposure to France, but does not show up in the TIC data; conversely, a purchase of corporate bond issued by the French parent in Paris would indeed represent a cross-border transaction captured by the TIC. On the other hand, the TIC data include foreign securities that are held by U.S. offices of foreign-headquartered banks because they are U.S.-resident investors and from a balance of payments perspective, that is a U.S.-to-foreign relationship. Similarly, the banking exposure data consolidate banks' worldwide exposures, effectively looking at the parent of the holder rather than the holder itself. So measures of U.S. bank exposure to Europe include not just securities held by domestic offices of U.S.-headquartered banks, but also what is held by the foreign offices of U.S. headquartered banks. Those positions are not included in the TIC because they do not represent a U.S.-to-foreign relationship from a balance of payments perspective. In addition, the banking exposure data also include bank lending in addition to securities holdings, and positions are adjusted for some hedges and collateral.

${ }^{4}$ Financial assets exclude direct investment and financial derivatives.
} 
term debt securities holdings are small, with a share of only 4 percent. Besides securities, bank claims, which are shown as net of affiliated office liabilities, account for about 16 percent. Panels A and B in Table 2 show detailed breakdown by security type of U.S. portfolio holdings abroad and in Europe, respectively. U.S. holdings of foreign securities, particularly equity, decline noticeably in 2008, when the great financial crisis in the United States was most intense. However, U.S. holdings have held up pretty well as of December 2011 during the European financial crisis, even in European securities.

\section{Patterns of U.S. Holdings and Net Investment Flows into Europe}

One way to compare the U.S. investor response during the current crisis with behavior during the global financial crisis is to look at how changes in U.S. portfolio shares have moved relative to shares of the respective securities in total market capitalization. Following standard presentations of the International Capital Asset Pricing Model (ICAPM), we construct a measure of "home bias" in all foreign bonds as 1 minus the ratio of (U.S. holdings of foreign bonds as a share of the total U.S. bond portfolio) to (total bonds outstanding issued by foreign countries as a share of all bonds outstanding):

Home_bias ${ }_{\text {Bond }}$

$$
=1-\frac{\frac{U . S . \text { holdings of foreign bonds }}{\text { total U.S.bond portfolio }(\text { domestic }+ \text { foreign bonds })}}{\frac{\text { total foreign bonds outstanding }}{\text { global bond market capitalzation (all U.S. }+ \text { all foreign bonds outstanding) }}}
$$

and similarly for U.S. holdings of foreign equity.

Likewise, we can construct measures of home bias against European bonds: 
Home_bias Eurbond $_{\text {Hom }}$

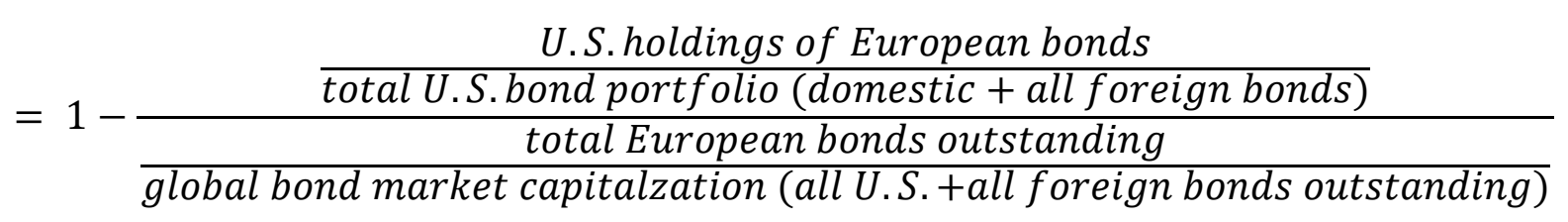

We construct similar measures for U.S. home bias against all foreign equity and European equity. If U.S. portfolio shares equal market capitalization shares, the ratio will equal 1 , and "home bias" will be zero; the closer this ratio is to 1, the higher the measure of "home bias". In practice, existing literature has found ample evidence of considerable home bias (see for example French and Poterba (1991) and Tesar and Werner (1995)).

Figures 2 and 3 show our calculations of U.S. home bias in bonds and equity from 2003 to 2011. U.S. bond home bias decreased in the years leading up to the global financial crisis (Figure 2, blue line), but then more than reversed this trend in 2008 as U.S. investors sold foreign bonds and reverted to holding a larger portfolio share in domestic bonds. But since the European debt crisis, U.S. bond home bias has again decreased. Given that the global bond market capitalization was little changed during the 2010-2011 period, the decreased U.S. bond home bias indicates that U.S. investors have continued to purchase foreign bonds, and moreover, these purchases have led to an increased portfolio share relative to market capitalization shares. In addition, U.S. investors have less bias against European bonds than against foreign bonds more generally, as the line for European bond home bias (the dashed red line) lies below the total home bias line, but otherwise U.S. investment behavior has behaved very similarly towards European and all foreign bonds. Figure 3 shows a similar result for U.S. home bias in foreign and European equity: overall equity home bias as well as European home bias did increase during the global financial crisis as U.S. investors sold off foreign equity, but has since 
recovered, with U.S. investor shares moving apparently proportionately with market capitalization shares.

Table 3 highlights some of the differences between the two crisis periods by decomposing annual changes in U.S. holdings of all foreign long-term securities into valuation, or price, changes and net investment flows. ${ }^{5}$ U.S. holdings of foreign equity plummeted in 2008. This decline is primarily from valuation losses as foreign equity prices tumbled, but U.S. investors also sold a small amount of foreign stocks that year. In 2011, equity again registered sizable valuation losses, but U.S. investors continued to make positive, although small, investments. Similarly, U.S. investors sold foreign long-term bonds in 2008, but have since been making sizable net purchases, consistent with the continued decrease of U.S. investors' home bias as shown in Figure 2.

Table 3 also compares net flows into European securities and flows into other foreign securities. We find that U.S. investors have also continued to add to their holdings of European securities during the European debt crisis, although at a somewhat reduced rate. The positive net investment in long-term European debt in 2011 (\$71 billion) stands in contrast to sizable sales in 2008 (-\$175 billion). One should note that, since Figure 2 shows that U.S. investors' "European bias" has not increased again during the most recent crisis, the slower pace of U.S. investment into European bonds that we see in our cross-border data has apparently been proportionate to changes in European bond market capitalization. Overall, the European crisis appears to have induced a smaller reaction by U.S. investors than did the global financial crisis.

However, the observation that U.S. investors have not retreated from European bonds or equity does not mean that their current exposure does not continue to pose significant portfolio

\footnotetext{
${ }^{5}$ Because the surveys are collected as of the end of each calendar year, we have explicit price data for only these two observations. For securities that U.S. investors held in consecutive years, we assume that changes in holdings occur at the average of the previous year's price and current year's price.
} 
risks. Indeed, at \$2 trillion at end-2011, holdings of European equity account for nearly half of the U.S. cross-order equity portfolio, and also account for roughly $2 / 3$ of the U.S. portfolio investment in Europe. The potentially risky nature of those holdings is evident by the large losses U.S. investors took especially on equity holdings during the global financial crisis. And, by our estimates, U.S. investors lost a further \$269 billion on their holdings of European equity in 2011. One potential explanation for why U.S. investors have not pulled back from European equity even during periods of crisis is that U.S. holdings appear to be concentrated in large multinational corporations, with losses in 2011 of about -14 percent of 2010 U.S. holdings right on par with the return of MSCI European stock index. Thus, although U.S. investors have considerable exposure to European equity, their holdings appear similar to the composition of the broad market index, rather than exposure to particularly volatile segments of the market.

Looking into the composition of recent investment flows in a little more detail, we further see that of the small positive investments U.S. investors have made into European equity in 2011, as shown in Table 4, almost all flowed to the non-financial sector, with flows into the financial sector near zero, while valuation losses on holdings of financial sector equity were considerably larger than were losses on non-financial sector equity. Thus, U.S. investors have focused their new equity investment flows on the (relatively) stronger performing nonfinancial sector.

We next turn to U.S. investment in European long-term debt securities, focusing our analysis on European long-term debt securities issued by the government and financial sectors, the two largest portions of the U.S. portfolio most directly related to the European financial crisis. Table 5 shows that as of end-2011, more than 40 percent of U.S. holdings of European long-term debt securities are in financial sector debt and about one quarter are in government 
sector debt. ${ }^{6}$ Europe is defined to include emerging Europe and non-euro area countries, not just the euro area, because of exposures and financial and real economy linkages across European countries. On average from 2007 to 2011, about half of U.S. holdings of foreign long-term debt securities are of European debt. While holdings of European debt are a relatively small share of the total U.S. portfolio, they nonetheless amount to nearly \$1 trillion - large enough to represent a risk.

However, the TIC data confirm that relatively little of U.S. holdings of European debt securities are claims on the most vulnerable European countries and currencies. As shown in Table 6, most of our holdings of European debt are concentrated in the core euro-area countries and the United Kingdom, which together account for about three fourths of total European debt held. Debt issued by the peripheral countries amounted to $\$ 83$ billion, accounting for less than 10 percent of the $\$ 1$ trillion in total European debt held.

As shown in Table 7, investors in the "Other” category including banks, security brokerdealers, and hedge funds as well as non-financial corporations and other types of investors together hold about 41 percent of European debt - a smaller share than they held of foreign ABS before the global financial crisis. Mutual funds, the second largest category, account for 30 percent. Pension funds and insurance companies together account for another 30 percent. The holdings of euro peripheral debt are largest for “Other,” but still it is relatively small, less than 10 percent of their holdings of European long-term debt securities.

Furthermore, as indicated in Table 8, about 70 percent of total European debt held in 2011 was dollar-denominated. Holdings of debt denominated in euros and other currencies are concentrated in government debt. The concentration of U.S. holdings in dollar-denominated

\footnotetext{
${ }^{6}$ We categorize the issuers of European debt securities using the Global Industry Classification Standard (GICS). The non-financial sector is defined as all sectors except government and financial.
} 
debt in core euro-area countries and the United Kingdom helps explain why overall European holdings have held up during the crisis.

To investigate how U.S. investors allocate their new investment, we decompose net investment flows into European debt by sector, as shown in Figure 4. During the global financial crisis, as U.S. investors pulled back from European long-term debt, most of the debt they sold was concentrated in the financial sector and the government sector. In 2011, about two thirds, $\$ 40$ billion, of the net debt they purchased was government debt. Flows to the non-financial corporate sector accounted for the remainder. ${ }^{7}$ Net investment into the financial sector, however, was essentially zero in 2011. The drying up of U.S. financing for this sector could reflect growing counterparty risk concerns. But another factor could be that the supply of financial debt may have been reduced by deleveraging on the part of the European banks. We explore this idea more thoroughly in section 4.2 below.

\section{Compositional Changes in U.S. Investment in European Government and Financial Debt}

\subsection{Government debt securities}

To shed some light on U.S. investors’ continued interest in European government debt, we take a closer look at its composition. As shown in Table 8, the government sector is the only sector where U.S. holdings are not predominantly dollar-denominated. The shares of dollar and other currencies have both increased from 10 percent in 2007 to 18 percent in 2011, mainly due to investors' growing interest in Eastern European government debt denominated in both dollar and local currencies. On the other hand, shares of euro- and sterling-denominated debt decreased 12 percent and 5 percent, respectively.

\footnotetext{
${ }^{7}$ The non-financial sector is defined as all sectors except government and financial.
} 
We also look into net investment flows into European government debt by region, as shown in Figure 5. The largest flows in 2010 and 2011 have been into government debt of Eastern European countries, in particular, Poland and Hungary, which helps explain the increase in the share of holdings in currencies other than the dollar, euro, or pound. Flows to U.K. government debt were also substantial. But somewhat surprisingly, net investment flows to peripheral debt exceeded flows to the core euro area countries in 2011. Out of the $\$ 12$ billion net inflows to the peripheral sovereign debt, about half was in Italian debt, followed by Irish and Spanish debt. We also find that inflows into Eastern European and peripheral government debt in 2011 were mainly from mutual funds and "Other" type of U.S. investors that might be most likely to reach for yield.

Given the continued U.S. investor interest in European sovereign debt, even those issued by the peripheral countries, we next explore the determinants of U.S. holdings. Looking in aggregate at all U.S. investors, both "safety” factors, such as managing credit and counterparty risk, and "reaching for yield" factors, appear to have influenced portfolio allocations. Using panel data for 19 European countries over the 2006-2011 period, we study the effect on percentage of U.S. holdings of the perceived credit risk and sovereign yield spread over the U.S. Treasury yield. ${ }^{8}$ Our baseline regression is:

$$
\text { Pct_holdings }_{i, t}=\alpha+\beta_{1} C D S_{i, t}+\beta_{2} Y_{-} \text {spread }_{i, t}+\delta^{\prime} X_{i, t}+\varepsilon_{i, t}
$$

where Pct_holdings $s_{i, t}$ denotes U.S. holdings as percentage of amount outstanding of sovereign debt in country $i$ in year $t, C D S_{i, t}$ denotes the 5-year credit default swap (CDS) spread for country $i$ in year $t, Y_{-}$spread $_{i, t}$ denotes the weighted-average sovereign bond yield spread over

\footnotetext{
${ }^{8}$ The countries in our sample are Austria, Belgium, Czech Republic, Denmark, Finland, France, Germany, Hungary, Ireland, Italy, Netherlands, Norway, Poland, Portugal, Sweden, Switzerland, Turkey, and United Kingdom. Greece is excluded as an outlier.
} 
the 10-year U.S. Treasury yield for country $i$ in year $t$, and $X_{i, t}$ is a vector of control variables, including year dummies $D_{2010}, D_{2011}$, and interaction terms between year dummies and CDS spread and return spread, respectively.

We perform both pooled OLS regression and a regression with country fixed effects. Regression results are qualitatively similar, as presented in columns (1) and (2) respectively in Table 9. Our main finding is that both safety and "reaching for yield" factors appear to be important drivers of capital flows into European government debt during the period. In general, lower CDS spread and higher yield spread are associated with higher U.S. holdings. Between these two offsetting motives, the safety factor seemed to dominate. During the European crisis, however, the positive coefficients on the two interaction terms with yield spread show that the role of the yield factor was amplified in 2010 and 2011, especially in 2011, while the positive although insignificant coefficients on the interaction terms with CDS suggest that country credit risk became less offsetting. In terms of economic significance, column (2) shows that, a onestandard deviation increase in the sovereign yield spread in 2011 would induce an increase in the holding percentage of 0.32 percentage points, other things equal. Given that U.S. investors held, on average, no more than 2 percent of the amount outstanding of any country's government debt, this is economically significant. U.S. Treasury yields were especially low in 2011, and this result suggests that high foreign yields might matter more when U.S. (and also core euro area) yields are especially low. This in turn helps explain why U.S. investors seemed to favor higheryielding Eastern European and peripheral sovereign debt in $2011 .^{9}$

Since our sample includes a wide range of U.S. investors with different investment objectives, we look into the cross-sectional differences in holdings across the broad categories of

\footnotetext{
${ }^{9}$ We also find adding a region dummy (such as an Euro/Non-Euro dummy or a periphery/non-periphery dummy) in the regression does not significantly affect the result and therefore it is not reported here.
} 
investors available in the TIC data. We repeat regression (1) with country fixed effects for each of the four categories of investors that we can identify: mutual funds, pension funds, insurance companies, and other investors. The results are reported in Table 10. Interestingly, the “reaching-for-yield” factor was significant across almost all investor types in 2011 except pension funds, and it is most significant for mutual funds, followed by "Other”. Mutual funds are usually known as return-driven investment vehicles. The "Other" category, which includes banks, broker-dealers, hedge funds, and non-financial corporations, did account for some of the increase in Eastern European and peripheral euro area debt in 2011. Insurance companies, especially life insurers, are required to pay a minimum guaranteed return on their liabilities. As insurers' earnings declined in recent years, they may have been motivated to reach for yield in their fixed-income investments in the current low interest environment. Pension funds also seem to reach for yield to some extent, but just not significantly.

How well did this "reach for yield" strategy work for U.S. investors? To answer this question, we compute weighted average returns on U.S. holdings of European government debt, and estimate how portfolio adjustments contributed to returns in recent years, as presented in Table 11. In particular, we first calculate the weighted average return on government bonds (i.e., coupon payment divided by price) for each country in each year, and then use the total government debt holdings for each country as the weight to compute total returns on European government debt holdings.

Since 2008, returns on most government debt have been declining, largely due to the low interest rate environment and "flight to safety" flows that have pushed down yields on government debt of core European countries. The average return earned by U.S. investors on European government debt holdings also declined, from 4.28 percent in 2009 to 4.20 percent in 
2010 and only 4.14 percent in 2011. However, Table 11 shows that U.S. investors did improve on their returns on European government debt holdings by "reaching for yield" through their portfolio adjustments. In particular, had U.S. investors maintained the 2007 portfolio weight, the “pseudo” returns in 2010 and 2011 would have been 49 and 53 basis points lower than the actual returns, respectively. Similarly, if U.S. investors had maintained the 2009 portfolio weights, the “pseudo” returns in 2010 and 2011 would have been 12 and 16 basis points lower, respectively. These differences largely reflect the payoff of portfolio adjustments towards higher-yielding European government debt in recent years. Even though security level data from the 2012 claims survey are not yet available, our 2012 return estimate based on aggregated holdings data from TIC SLT for December 2012 is consistent with our findings: U.S. investors’ return on European government debt holdings has continued to decline, but it was still notably higher than those without any portfolio adjustments.

\subsection{Financial debt securities}

In this final section we look at U.S. investment in European financial debt. U.S. holdings of European long-term financial debt securities amounted to \$373 billion as of end 2011, accounting for the largest share (more than 40 percent) of total European long-term debt holdings. As discussed in Section 3, we saw little net investment into European financial debt in 2010 and 2011. While this could reflect discrimination on the part of U.S. investors away from risky financial sector debt, it might simply reflect changes in issuance over the past couple years. Indeed, as shown in Figure 6, net issuance of European financial sector debt has fallen off sharply. However, it has still remained positive, whereas U.S. net investment has been nil. 
We find additional evidence of active portfolio management on the part of U.S. investors in their allocation to European asset-backed securities (ABS). Table 12 shows that U.S. investment flows to ABS have been negative in 2010 and 2011, offsetting flows into other forms of financial debt securities. Furthermore, we find that most of the decrease in net inflows to ABS was due to outright sales of ABS still outstanding rather than a passive strategy reflecting maturity of ABS securities held.

We also investigate whether U.S. investors have actively worked to maintain the credit quality of their holdings of European financial debt. As shown in the first row of Table 13, of all financial debt held, the share of bonds that Moody's rated AAA edged down from 40 percent in 2010 to 38 percent in 2011. This shift is mainly due to the overall deterioration of credit ratings in the financial sector: a smaller fraction of total European financial debt was rated AAA in December 2011 than in the previous year. However, the share of AAA bonds among all bonds added to the portfolio (that is, both newly-issued bonds and existing bonds) was 39 percent in 2010 and 41 percent in 2011, higher than the AAA share of bonds shed from the portfolio (reflecting both maturities and bond sold). The difference between the AAA share in bonds added to and bonds shed from the U.S. portfolio became larger in 2011, suggesting that U.S. investment flow shifted more towards highly rated financial debt despite their decreased availability as credit conditions worsened.

On the other hand, U.S. holdings of non-financial corporate debt securities have stayed fairly stable in the crisis years (see Table 5). For instance, in 2008, U.S. holdings of long-term non-financial debt securities dropped by $\$ 14$ billion out from the $\$ 192$ billion held in 2007, a tiny amount compared to decline in financial and government sector debt securities in the same year. And U.S net investment into the non-financial sector has been positive in subsequent 
years, as shown in Figure 4. The stability of U.S. investment in the European non-financial sector, in part, reflects that much of these holdings are in dollar-denominated bonds issued by multinational corporations headquartered in Europe, and thus are less directly affected by the current European crisis than are firms in the financial sector.

Finally, we analyze cross-sectional differences in U.S. holdings of European financial debt by taking a closer look at a sub-sample of financial debt issued by major European banks. Londono-Yarce, Vega, and Zdinak (2012) find that a financial institution i’s contribution to a recently developed systemic risk measure, SRisk, an estimate of the capital shortfall of institution $i$ during times of aggregate financial distress, can help predict financial vulnerabilities in Europe during the financial crisis. ${ }^{10}$ We look at a sub-sample of financial debt issued by 43 large European banks covered in both their sample and our data, and examine how U.S. holdings of financial debt issued by these banks vary with this new risk measure and across different banklevel and security-level characteristics: ${ }^{11}$

$$
\begin{aligned}
\text { Pct_held }_{i, t}= & \alpha+\beta_{1} \text { HR }_{i, t}+\beta_{2} \text { Yield }_{i, t}+\beta_{3} \ln \left(B A_{i, t}\right)+\beta_{4}\left(\text { SRisk }_{i t} / B A_{i, t}\right) \\
& +\beta_{5} \text { CDS }_{i, t}+\delta^{\prime} X_{i, t}+\varepsilon_{i, t}
\end{aligned}
$$

where $P c t_{-} h e l d_{i, t}$ denotes U.S. holdings of financial debt security $i$ as share of total European financial debt held in year $t$. For security level characteristics, we use a Moody’s high rating dummy $H R_{i, t}$ (for credit ratings higher than Aa3) and bond yield. For issuer bank characteristics, we use (1) $\ln \left(B A_{i, t}\right)$, the natural log of bank asset $B A_{i, t}$, (2) $S R i s k_{i, t} B A_{i, t}$, a measure of relative riskiness of issuing bank of security $i$ after controlling for the bank assets $\left(B A_{i, t}\right)$ since $S R i s k_{i, t}$ is highly correlated with the magnitude of $B A_{i, t}$, and (3) $C D S_{i, t}$, the 5-year credit default swap

\footnotetext{
${ }^{10}$ For details on how SRisk is computed, see Brownlees and Engle (2011) and Londono-Yarce, Vega, and Zdinak (2012).

${ }^{11}$ The sub-sample accounts for about 40 percent of the total European financial debt held.
} 
(CDS) spread for security $i$ 's issuing bank at end of year $t .{ }^{12} X_{i, t}$ is a vector of control variables, including year dummies $D_{2010}$ and $D_{2011}$, and interaction terms between year dummies and other independent variables.

Table 14 shows the result of panel regression (2). Column (1) is a pooled OLS regression while column (2) includes bank dummies to take into account bank fixed effects. The results suggest that U.S. investors' holdings of European financial debt are positively and significantly affected by security credit ratings and yield, as well as the size of the issuing bank, consistent with our findings that U.S. holdings are mostly concentrated in securities that are considered relatively safe. In addition, the interaction terms between rating and yield with year dummies suggest that investors seem to value more of high credit ratings and less of yield on the margin in 2010 and 2011, although the coefficient is not significant. The role of other bank level characteristics, on the other hand, seems less clear. The coefficient on SRisk is negative and insignificant in column (1), but becomes positive and marginally significant in column (2). The effect of issuer bank's CDS spread is also insignificant. The overall evidence indicates that U.S. investors' financial debt holdings are more closely correlated with security-specific characteristics than with those at the issuer bank level other than the bank size.

\section{Conclusion}

In this paper we present evidence that U.S. investors have not scaled back from long-term cross-border investment during the European debt crisis, even from Europe. This stands in sharp contrast to the pullback and increase in home bias during the 2007-2009 global financial crisis. Although net flows to European debt have slowed somewhat, the relative stability of European portfolios likely reflects a degree of discrimination in the kinds of European debt held by U.S.

\footnotetext{
${ }^{12}$ SRisk, $B A$ and $C D S$ values are averages of daily values in Q4.
} 
investors: Most debt holdings are dollar-denominated and most are in debt issued by core euroarea countries and the United Kingdom, which investors may see as relatively safe. During the European debt crisis, U.S. investors appear to have shunned the European financial sector, but have continued to invest in other sectors. Changes in the composition of holdings over the past couple years suggest that U.S. investors have behaved in a way that reflects their diversity and differing objectives: while they looked for higher yields in government debt, U.S. investors appeared to have shifted toward safer investments in the financial sector, perhaps reflecting lessons learned from losses during the global financial crisis. 


\section{References}

Ahearne, Alan G., William L. Griever, and Francis E. Warnock (2004), "Information costs and home bias: an analysis of US holdings of foreign equities," Journal of International Economics 62, 313-336.

Bernanke, Ben S., Carol C. Bertaut, Laurie P. DeMarco, and Steven Kamin (2011), "International Capital Flows and the Return to Safe Assets in the United States, 20032007,” Board of Governors of the Federal Reserve System, International Finance Discussion Paper 1014.

Bertaut, Carol C. and Laurie Pounder (2009), “The Financial Crisis and U.S. Cross-Border Financial Flows,” Federal Reserve Bulletin, November, A147-A167.

Bertaut, Carol, Laurie P. DeMarco, Steven Kamin, and Ralph Tryon (2012), “ABS inflows to the United States and the global financial crisis,” Journal of International Economics 88(2), 219-234.

Brennan, Michael, and Henry Cao (1997), “International Portfolio Investment Flows,” Journal of Finance 52, 1851-1880.

Brownlees, Christian T. and Robert Engle (2011), "Volatility, Correlation, and Tails for Systemic Risk Measurement,” New York University working paper.

Cao, Henry, Bing Han, David Hirshleifer, and Harold Zhang (2011), "Fear of the Unknown: Familarity and Economic Decisions,” Review of Finance 15(1), 173-206.

Choe, Hyuk, Bong-Chan Kho, and Rene Stulz (2005), "Do Domestic Investors Have an Edge? The Trading Experience of Foreign Investors in Korea,” Review of Financial Studies, 18(3), 795-829.

Cooper, Ian and Evi Kaplanis (1994), "What explains the home bias in portfolio investment?,” Review of Financial Studies 7(1), 45-60.

Coval, Joshua D., Jakub W. Jurek, and Erik Stafford (2008), "The Economics of Structured Finance," Harvard Business School Finance Working Paper No. 09-060. Boston, Mass.: Harvard Business School (October).

Demyanyk, Y., and O. Van Hemert (2009), “Understanding the Subprime Mortgage Crisis,” The Review of Financial Studies 24(6), 1848-1880.

Fratzscher, Marcel (2011), “Capital Flows, Push versus Pull Factors and the Global Financial Crisis”, European Central Bank working paper.

French, K. and J. Poterba (1991), “Investor diversification and international equity markets,” American Economic Review, Papers and Proceedings, 222-226. 
Forbes, Kristin J., and Francis E. Warnock (2011), “Capital Flows Waves: Surges, Stops, Flight, and Retrenchement,” Journal of International Economics 88, 235-251.

Gerardi, Kristopher, Andreas Lehnert, Shane Sherlund, and Paul Willen (2008), "Making Sense of the Subprime Crises," in Brookings Papers on Economic Activity, vol. 2 (Fall).

Washington: Brookings Institution Press, 69-145.

Gorton, Gary B. (2008), "The Panic of 2007," in Maintaining Stability in a Changing Financial System, proceedings of the 2008 Economic Policy Symposium. Kansas City: Federal Reserve Bank of Kansas City, 131-262.

Gorton, Gary B. (2009), "Information, Liquidity, and the (Ongoing) Panic of 2007," American Economic Review, Papers and Proceedings, vol. 99 (May), 567-572.

Gourinchas, Pierre-Olivier, Hélène Rey, and Kai Truempler (2012), “The financial crisis and the geography of wealth transfers,” Journal of International Economics 88(2), 266-283.

Huberman, Gur (2001), “Familiarity Breeds Investment,” Review of Financial Studies 14, 659680.

Karolyi, G. Andrew, and Rene M. Stulz (2003), “Are Assets Priced Globally or Locally?” Handbook of the Economics of Finance, edited by G.M. Constantinides, M. Harris and R. Stulz, Elsevier Science B.V., Chapter 15, 973-1018.

Lewis, Karen K. (2011), “Global Asset Pricing,” Annual Review of Financial Economics 3, 435466.

Londono-Yarce, Juan-Miguel, Clara Vega, and Michael Zdinak (2012), “Using Systemic Risk Measures to Understand Financial Vulnerabilities in the Euro Area”, working paper, Federal Reserve Board.

Milesi-Ferretti, Gian-Maria, and Cedric Tille (2011), “The Great Retrenchment: International Capital Flows During the Global Financial Crisis”, Economic Policy 26(66), 289-346.

Tarullo, Daniel (2012), "Shadow Banking After the Financial Crisis," Speech at the Federal Reserve Bank of San Francisco Conference on Challenges in Global Finance: The Role of Asia, San Francisco, California, June 12.

Tesar, Linda L., and Ingrid M. Werner (1995), “Home Bias and High Turnover,” Journal of International Money and Finance 14, 467-493.

Uppal, Raman, and Tan Wang (2003), "Model Misspecification and Under-diversification,” Journal of Finance 58(6), 2465-2486. 
Table 1. U.S. Credit Market Debt, Corporate Equity, and Mutual Fund Shares Outstanding

Billions of dollars except as noted

\begin{tabular}{|c|c|c|c|c|c|c|c|c|}
\hline & Total & $\begin{array}{c}\text { Equity \& } \\
\text { mutual fund } \\
\text { shares }\end{array}$ & $\begin{array}{l}\text { Total debt } \\
\text { securities }\end{array}$ & $\begin{array}{c}\text { Treasuries \& } \\
\text { agencies }\end{array}$ & $\begin{array}{c}\text { Open market } \\
\text { paper, } \\
\text { municipal } \\
\text { bonds, and } \\
\text { corporate } \\
\text { and foreign } \\
\text { bonds } \\
\end{array}$ & $\begin{array}{c}\text { Of which: } \\
\text { commercial } \\
\text { paper and } \\
\text { corporate } \\
\text { bonds of } \\
\text { asset-backed } \\
\text { issuers } \\
\end{array}$ & $\begin{array}{c}\text { Of which: } \\
\text { other } \\
\text { financial } \\
\text { debt }\end{array}$ & $\begin{array}{c}\text { Of which: } \\
\text { Municipal } \\
\text { and } \\
\text { nonfinancial } \\
\text { corporate } \\
\text { debt }\end{array}$ \\
\hline \multicolumn{9}{|l|}{ Total } \\
\hline 2000Q4 & 35,614 & 22,008 & 15,220 & 7,193 & 8,027 & 1,504 & 2,188 & 4,335 \\
\hline 2003Q4 & 40,959 & 21,293 & 19,667 & 9,311 & 10,356 & 2,223 & 2,435 & 5,698 \\
\hline 2007Q2 & 61,432 & 34,227 & 27,205 & 10,899 & 16,305 & 4,500 & 4,428 & 7,378 \\
\hline 2009Q1 & 49,518 & 18,878 & 30,640 & 14,101 & 16,539 & 3,925 & 4,447 & 8,168 \\
\hline \multicolumn{9}{|c|}{ Change from 2007Q2 to 2009Q1 } \\
\hline In dollars & $-11,913$ & $-15,349$ & 3,436 & 3,202 & 234 & -575 & 19 & 789 \\
\hline Percent & -19.4 & -44.8 & 12.6 & 29.4 & 1.4 & -12.8 & 0.4 & 10.7 \\
\hline \multicolumn{9}{|c|}{ Memo - for 2007Q4 } \\
\hline \multicolumn{5}{|c|}{ Held by insurance, pension funds, and mutual funds } & 6,239 & & & \\
\hline \multicolumn{5}{|c|}{ Held by U.S. chartered depository institutions } & 612 & 292 & & \\
\hline \multicolumn{4}{|c|}{ Held by foreign residents } & & 3,002 & 1,018 & & \\
\hline
\end{tabular}

Source: U.S. Flow of Funds Statistics and Treasury International Capital Reports. 
Table 2. U.S. Holdings of Foreign Securities by Type

Billions of dollars except as noted

\begin{tabular}{|c|c|c|c|c|}
\hline & Total & Equity & LT debt & ST debt \\
\hline \multicolumn{5}{|c|}{ Panel A: All Foreign Holdings } \\
\hline 2007 & $7,219.7$ & $5,252.9$ & $1,609.8$ & 357.0 \\
\hline 2008 & $4,291.5$ & $2,748.4$ & $1,260.6$ & 282.4 \\
\hline 2009 & $5,976.7$ & 3,995.3 & $1,594.2$ & 387.2 \\
\hline 2010 & $6,763.3$ & 4,646.9 & $1,714.8$ & 401.6 \\
\hline 2011 & $6,883.4$ & $4,498.4$ & $2,024.0$ & 361.0 \\
\hline \multicolumn{5}{|c|}{ Panel B: Total Holdings in Europe } \\
\hline 2007 & $3,654.8$ & $2,571.1$ & 813.2 & 270.5 \\
\hline 2008 & $2,171.8$ & 1,378.9 & 584.9 & 208.0 \\
\hline 2009 & $3,000.6$ & 1,961.9 & 751.7 & 287.0 \\
\hline 2010 & $3,154.4$ & $2,113.4$ & 780.5 & 260.6 \\
\hline 2011 & 2,982.9 & 1,959.1 & 867.3 & 156.5 \\
\hline
\end{tabular}

Source: TIC. 
Table 3. Changes in U.S. Holdings of Foreign Securities by Type

Billions of dollars

\begin{tabular}{|c|c|c|c|c|}
\hline & Total & Equity & LT debt & ST debt \\
\hline \multicolumn{5}{|l|}{2007} \\
\hline Value changes & 394 & 406 & -12 & * \\
\hline Net Inv. Flows & 829 & 512 & 328 & -11 \\
\hline Of which: Europe & 386 & 235 & 167 & -16 \\
\hline Of which: other foreign & 443 & 277 & 161 & 5 \\
\hline \multicolumn{5}{|l|}{2008} \\
\hline Value changes & $-2,613$ & $-2,458$ & -155 & $*$ \\
\hline Net Inv. Flows & -298 & -34 & -189 & -75 \\
\hline Of which: Europe & -183 & 55 & -175 & -63 \\
\hline Of which: other foreign & -115 & -89 & -14 & -12 \\
\hline \multicolumn{5}{|l|}{2009} \\
\hline Value changes & 1,035 & 983 & 97 & $*$ \\
\hline Net Inv. Flows & 595 & 257 & 233 & 105 \\
\hline Of which: Europe & 350 & 149 & 122 & 79 \\
\hline Of which: other foreign & 245 & 108 & 111 & 26 \\
\hline \multicolumn{5}{|l|}{2010} \\
\hline Value changes & 331 & 300 & 31 & $*$ \\
\hline Net Inv. Flows & 448 & 343 & 91 & 14 \\
\hline Of which: Europe & 74 & 82 & 18 & -26 \\
\hline Of which: other foreign & 374 & 261 & 73 & 40 \\
\hline \multicolumn{5}{|l|}{2011} \\
\hline Value changes & -671 & -695 & 24 & $*$ \\
\hline Net Inv. Flows & 182 & 36 & 187 & -41 \\
\hline Of which: Europe & 9 & 42 & 71 & -104 \\
\hline Of which: other foreign & 173 & -6 & 116 & 63 \\
\hline
\end{tabular}

Source: TIC surveys and authors' calculations.

* Valuation changes for short-term debt are minimal and thus omitted. 
Table 4. U.S. Investment in European Equity

Billions of dollars

\begin{tabular}{c|ccccc}
\hline & 2007 & 2008 & 2009 & 2010 & 2011 \\
\hline Total U.S. holdings & 2,569 & 1,379 & 1,962 & 2,113 & 1,959 \\
Valuation change* & 149 & $-1,232$ & 425 & 58 & -269 \\
Net investment* & 202 & 30 & $9^{* *}$ & 72 & 77 \\
Of which: financial sector & 543 & 244 & 413 & 421 & 328 \\
Valuation change* & -68 & -308 & 77 & -29 & -89 \\
Net investment* & 33 & 13 & 55 & 28 & 1 \\
\hline
\end{tabular}

Source: TIC surveys and authors' calculations.

*Common stocks only.

** Excluded reincorporation of some Cayman and Bermuda corporations in Ireland and Switzerland in 2008.

Table 5. U.S. Investment in European Long-term Debt Securities by Sector

Billions of dollars

\begin{tabular}{l|ccccc}
\hline & 2007 & 2008 & 2009 & 2010 & 2011 \\
\hline Total & 812 & 585 & 751 & 780 & 867 \\
$\quad$ Government & 201 & 144 & 156 & 166 & 210 \\
Financial & 419 & 263 & 355 & 358 & 373 \\
$\quad$ Non-financial sector & 192 & 178 & 240 & 256 & 284 \\
\hline
\end{tabular}


Table 6. U.S. Investment in European LT Debt by Region

Billions of dollars except as noted

\begin{tabular}{l|ccccc}
\hline & 2007 & 2008 & 2009 & 2010 & 2011 \\
\hline Core EA & 307.7 & 263.0 & 341.9 & 337.1 & 367.4 \\
\% of total & $38 \%$ & $45 \%$ & $45 \%$ & $43 \%$ & $42 \%$ \\
Periphery & 113.9 & 62.3 & 69.9 & 64.5 & 81.5 \\
\% of total & $14 \%$ & $11 \%$ & $9 \%$ & $8 \%$ & $9 \%$ \\
U.K. & 286.7 & 185.4 & 240.3 & 253.0 & 293.3 \\
\% of total & $35 \%$ & $32 \%$ & $32 \%$ & $32 \%$ & $34 \%$ \\
Other Europe & 104.9 & 74.2 & 99.6 & 125.8 & 125.1 \\
\% of total & $13 \%$ & $13 \%$ & $13 \%$ & $16 \%$ & $14 \%$ \\
\hline Total European bonds & 813.2 & 584.9 & 751.7 & 780.5 & 867.3 \\
\hline
\end{tabular}

Table 7. European LT Debt Holdings by Investor Type by Region in 2011

Billions of dollars

\begin{tabular}{l|ccccc}
\hline & $\begin{array}{c}\text { Mutual } \\
\text { funds }\end{array}$ & $\begin{array}{c}\text { Pension } \\
\text { funds }\end{array}$ & $\begin{array}{c}\text { Insurance } \\
\text { companies }\end{array}$ & Other & Total \\
\hline Core EA & 127.3 & 43.6 & 98.1 & 195.1 & 464.1 \\
Periphery & 27.3 & 6.8 & 15.2 & 30.2 & 79.5 \\
U.K. & 79.9 & 29.2 & 64.4 & 119.8 & 293.3 \\
Other Europe & 40.5 & 5.1 & 6.8 & 28.0 & 80.4 \\
\hline
\end{tabular}


Table 8. Percentage of U.S. Holdings of European Debt by Currency by Sector

Percent

$2007 \quad 2008 \quad 2009 \quad 2010 \quad 2011$

\section{Total}

EUR

$22 \%$

$23 \%$

$22 \%$

$18 \%$

$19 \%$

GBP

USD

$7 \%$

$5 \%$

$4 \%$

$5 \%$

$6 \%$

Other

$67 \%$

$67 \%$

$70 \%$

$71 \%$

$70 \%$

$5 \%$

$5 \%$

$4 \%$

$5 \%$

$5 \%$

\section{Government}

$\begin{array}{lccccc}\text { EUR } & 60 \% & 63 \% & 57 \% & 51 \% & 49 \% \\ \text { GBP } & 20 \% & 12 \% & 9 \% & 13 \% & 15 \% \\ \text { USD } & 10 \% & 14 \% & 19 \% & 18 \% & 18 \% \\ \text { Other } & 10 \% & 11 \% & 15 \% & 18 \% & 18 \%\end{array}$

Financial

$\begin{array}{lccccc}\text { EUR } & 9 \% & 13 \% & 17 \% & 13 \% & 11 \% \\ \text { GBP } & 3 \% & 2 \% & 4 \% & 4 \% & 4 \% \\ \text { USD } & 84 \% & 80 \% & 77 \% & 81 \% & 83 \% \\ \text { Other } & 4 \% & 5 \% & 2 \% & 2 \% & 2 \%\end{array}$

Non-financial corporate

EUR
GBP
USD

\begin{tabular}{ccccc}
$8 \%$ & $7 \%$ & $6 \%$ & $6 \%$ & $7 \%$ \\
$3 \%$ & $2 \%$ & $2 \%$ & $2 \%$ & $2 \%$ \\
$88 \%$ & $91 \%$ & $92 \%$ & $92 \%$ & $91 \%$ \\
$1 \%$ & $0 \%$ & $0 \%$ & $0 \%$ & $0 \%$ \\
\hline
\end{tabular}




\section{Table 9. Determinants of U.S. Holdings of European Government Debt}

The results are from the panel regression using annual data from December 2006 to December 2011 for 19 countries (excluding Greece as an outlier). In column (1), U.S. holdings of a country's sovereign debt as percentage of its amount outstanding (Pct_holdings ) is regressed on the country's 5-year CDS spread $\left(\mathrm{CDS}_{t}\right)$, its 10-year yield spread over the U.S. Treasury yield $\left(Y_{-}\right.$spread $\left._{t}\right)$, year dummy variables for 2010 and 2011 ( $D_{2010}$ and $D_{2011}$ ), as well as the interaction terms between the year dummies and the CDS spread and yield spread, respectively. Column (2) controls for country fixed effects. ***, **, * denote significance at 1,5 , and 10 percent significance levels respectively.

(1)

Pooled OLS
(2)

With country fixed effects

\begin{tabular}{ccc}
\hline CDS & -0.50 & $-0.39^{*}$ \\
& $(0.38)$ & $0.24)$ \\
$Y_{\text {_spread }}$ & 0.24 & 0.18 \\
& $(0.18)$ & $(0.15)$ \\
$D_{2010}$ & -0.05 & -0.37 \\
& $(0.69)$ & $(0.41)$ \\
$D_{2011}$ & -1.28 & $-1.33^{* * *}$ \\
& $(0.85)$ & $(0.63)$ \\
$D_{2010} * C D S_{t}$ & -0.08 & 0.26 \\
& $(0.47)$ & $(0.28)$ \\
$D_{2011} *$ CDS & -0.28 & 0.04 \\
& $(0.45)$ & $(0.27)$ \\
$D_{2010} * Y_{-}$spread $_{t}$ & $0.72^{*}$ & 0.38 \\
& $(0.41)$ & $(0.25)$ \\
$D_{2011} * Y_{-}$spread $_{t}$ & $1.57^{* * *}$ & $1.15^{* * *}$ \\
& $(0.47)$ & $(0.28)$ \\
\hline \# of Observations & 110 & 110 \\
R-square & 0.19 & 0.21 \\
\hline
\end{tabular}




\section{Table 10. Determinants of Holdings of European Government Debt by Investor Type}

The results are from panel regression (1) using annual data from December 2006 to December 2011 for 19 countries (excluding Greece as an outlier) by investor type, controlling of country fixed effects. U.S. holdings of a country's sovereign debt as percentage of its amount outstanding (Pct_holdings) is regressed on the country's 5-year CDS spread (CDS), its 10-year yield spread over the U.S. Treasury yield (Y_spread), year dummy variables for 2010 and $2011\left(D_{2010}\right.$ and $\left.D_{2011}\right)$, as well as the interaction terms between the year dummies and the CDS spread and yield spread, respectively. ${ }^{* * *}, * *, *$ denote significance at 1,5 , and 10 percent significance levels respectively.

\begin{tabular}{|c|c|c|c|c|}
\hline & Mutual funds & Pension funds & $\begin{array}{l}\text { Insurance } \\
\text { companies }\end{array}$ & Other \\
\hline \multirow[t]{2}{*}{$C D S$} & -0.23 & $-0.06^{* *}$ & $-0.02^{*}$ & -0.08 \\
\hline & $(0.18)$ & $(0.03)$ & $(0.01)$ & $(0.08)$ \\
\hline \multirow[t]{2}{*}{$Y \_$spread } & 0.14 & -0.00 & 0.01 & -0.01 \\
\hline & $(0.11)$ & $(0.02)$ & $(0.01)$ & $(0.05)$ \\
\hline \multirow[t]{2}{*}{$D_{2010}$} & 0.08 & $-0.15^{* * *}$ & -0.00 & $-0.25^{*}$ \\
\hline & $(0.31)$ & $(0.05)$ & $(0.02)$ & $(0.13)$ \\
\hline \multirow{2}{*}{$D_{2011}$} & $-0.80^{* *}$ & $-0.18^{* * *}$ & $-0.05^{* *}$ & $-0.30^{*}$ \\
\hline & $(0.40)$ & $(0.07)$ & $(0.02)$ & $(0.17)$ \\
\hline \multirow[t]{2}{*}{$D_{2010} * C D S$} & 0.08 & $0.09^{* *}$ & 0.02 & 0.07 \\
\hline & $(0.21)$ & $(0.03)$ & $(0.01)$ & $(0.09)$ \\
\hline \multirow[t]{2}{*}{$D_{2011} * C D S$} & -0.04 & $0.07^{* *}$ & 0.01 & -0.04 \\
\hline & $(0.20)$ & $(0.03)$ & $(0.01)$ & $(0.09)$ \\
\hline \multirow[t]{2}{*}{$D_{2010} * Y \_s p r e a d$} & 0.29 & 0.01 & 0.00 & 0.10 \\
\hline & $(0.19)$ & $(0.03)$ & $(0.01)$ & $(0.08)$ \\
\hline \multirow[t]{2}{*}{$D_{2011} * Y \_s p r e a d$} & $0.91^{* * *}$ & 0.04 & $0.02^{*}$ & $0.28^{* * *}$ \\
\hline & $(0.21)$ & $(0.04)$ & $(0.01)$ & $(0.09)$ \\
\hline \# of Observations & 110 & 110 & 110 & 110 \\
\hline R-square & 0.34 & 0.04 & 0.13 & 0.05 \\
\hline
\end{tabular}


Table 11. Weighted average return on government debt held

Percent

\begin{tabular}{l|llllll}
\hline & 2007 & 2008 & 2009 & 2010 & 2011 & $2012 *$ \\
\hline Weighted average return & 4.27 & 4.36 & 4.28 & 4.20 & 4.14 & 2.90 \\
"Pseudo" return using 2007 weight & & 4.20 & 3.96 & 3.71 & 3.61 & 2.03 \\
$\quad$ Difference using 2007 weight & & 0.16 & 0.32 & 0.49 & 0.53 & 0.87 \\
"Pseudo" return using 2009 weight & & & & 4.08 & 3.98 & 2.18 \\
$\quad$ Difference using 2009 weight & & & & 0.12 & 0.16 & 0.72 \\
\hline
\end{tabular}

*Security level data from the 2012 claims survey not available yet; estimated with 10-year sovereign yields and aggregated holdings data from TIC SLT for December 2012.

Table 12. Net investment flows to financial debt: ABS vs. non-ABS

Billions of dollars

\begin{tabular}{l|ccccc}
\hline & 2007 & 2008 & 2009 & 2010 & 2011 \\
\hline ABS & 15 & -32 & 1 & -18 & -9 \\
Non-ABS & 53 & -81 & 67 & 14 & 7 \\
\hline
\end{tabular}

Table 13. Share of financial debt with Moody's AAA rating

Percent

\begin{tabular}{l|ccccc}
\hline & 2007 & 2008 & 2009 & 2010 & 2011 \\
\hline All financial debt held & $31 \%$ & $36 \%$ & $42 \%$ & $40 \%$ & $38 \%$ \\
Bonds added to portfolio & $23 \%$ & $30 \%$ & $46 \%$ & $39 \%$ & $41 \%$ \\
Bonds shed from portfolio & $17 \%$ & $13 \%$ & $14 \%$ & $31 \%$ & $21 \%$ \\
\hline
\end{tabular}




\section{Table 14. Determinants of U.S. Holdings of European Financial Debt}

The results are from panel regression (2) using annual data from December 2007 to December 2011 for a subsample of U.S. holdings of financial debt securities issued by 43 major European banks. In column (1), U.S. holdings of a financial debt security sovereign debt as percentage of the total financial debt held (Pct_held ${ }_{t}$ ) is regressed on the security's credit rating dummy $(H R)$ and yield, as well as the issuer bank's 5-year CDS spread (CDS $)$, its relative systemic risk contribution (SRisk/BA), bank assets $\ln (B A)$, year dummy variables for 2010 and $2011\left(D_{2010}\right.$ and $\left.D_{2011}\right)$, as well as the interaction terms, respectively. In column (2), we include individual bank dummies to control of bank fixed effect. $* * *, * *, *$ denote significance at 1,5 , and 10 percent significance levels respectively.

\begin{tabular}{|c|c|c|}
\hline & $\begin{array}{c}(1) \\
\text { Pooled OLS }\end{array}$ & $\begin{array}{c}\text { (2) } \\
\text { With issuer bank dummies }\end{array}$ \\
\hline Constant & $\begin{array}{l}-0.58 * * * \\
(-5.44)\end{array}$ & $\begin{array}{l}-1.31^{*} \\
(-1.85)\end{array}$ \\
\hline$H R$ & $\begin{array}{l}0.05^{* * * *} \\
(2.91)\end{array}$ & $\begin{array}{l}0.07 * * * \\
(3.57)\end{array}$ \\
\hline Yield & $\begin{array}{l}0.01^{* *} \\
(2.54)\end{array}$ & $\begin{array}{l}0.01^{* *} \\
(2.19)\end{array}$ \\
\hline $\ln (B A)$ & $\begin{array}{l}0.05^{* * * *} \\
(6.59)\end{array}$ & $\begin{array}{l}0.09 * \\
(1.94)\end{array}$ \\
\hline SRisk/BA & $\begin{array}{c}-0.23 \\
(-0.60)\end{array}$ & $\begin{array}{l}0.95^{*} \\
(1.79)\end{array}$ \\
\hline$C D S$ & $\begin{array}{c}0.01 \\
(0.33)\end{array}$ & $\begin{array}{c}-0.04 \\
(-1.63)\end{array}$ \\
\hline$D_{2010}$ & $\begin{array}{c}0.01 \\
(0.26)\end{array}$ & $\begin{array}{c}-0.05 \\
(-1.22)\end{array}$ \\
\hline$D_{2011}$ & $\begin{array}{c}-0.00 \\
(-0.01)\end{array}$ & $\begin{array}{l}-0.01 * * \\
(-2.01)\end{array}$ \\
\hline$H R * D_{2010}$ & $\begin{array}{c}0.00 \\
(0.10)\end{array}$ & $\begin{array}{c}0.01 \\
(0.44)\end{array}$ \\
\hline$H R * D_{2011}$ & $\begin{array}{c}0.04 \\
(1.35)\end{array}$ & $\begin{array}{c}0.03 \\
(1.10)\end{array}$ \\
\hline Yield $* D_{2010}$ & $\begin{array}{c}-0.00 \\
(-1.04)\end{array}$ & $\begin{array}{c}-0.00 \\
(-0.72)\end{array}$ \\
\hline Yield $* D_{2011}$ & $\begin{array}{c}-0.00 \\
(-0.95)\end{array}$ & $\begin{array}{c}-0.00 \\
(-0.62)\end{array}$ \\
\hline \# of Observations & 1190 & 1190 \\
\hline R-square & 0.07 & 0.17 \\
\hline
\end{tabular}


Figure 1. U.S. Holdings of Foreign Financial Assets

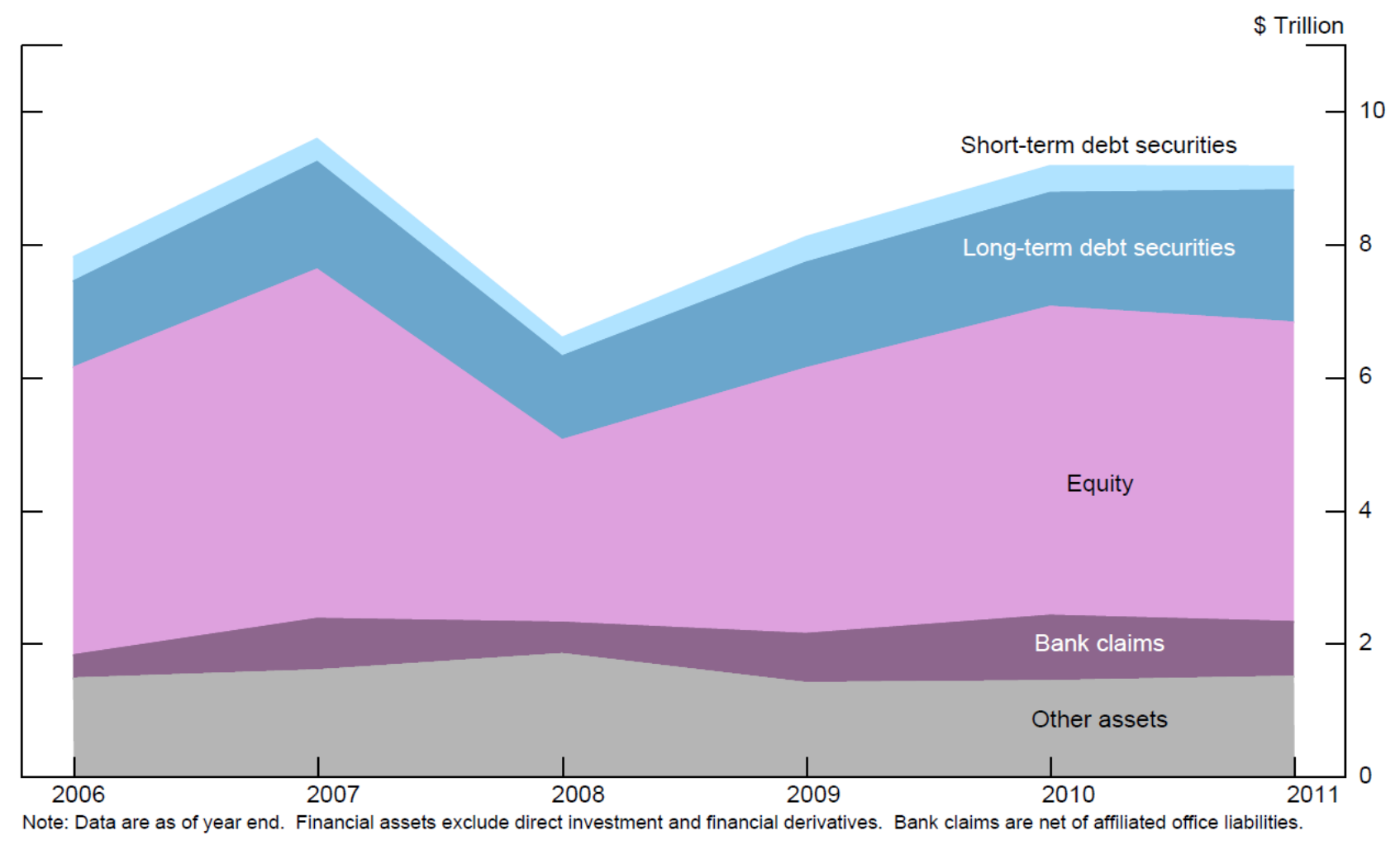


Figure 2. Home Bias in U.S. Holdings of Foreign and European Bonds

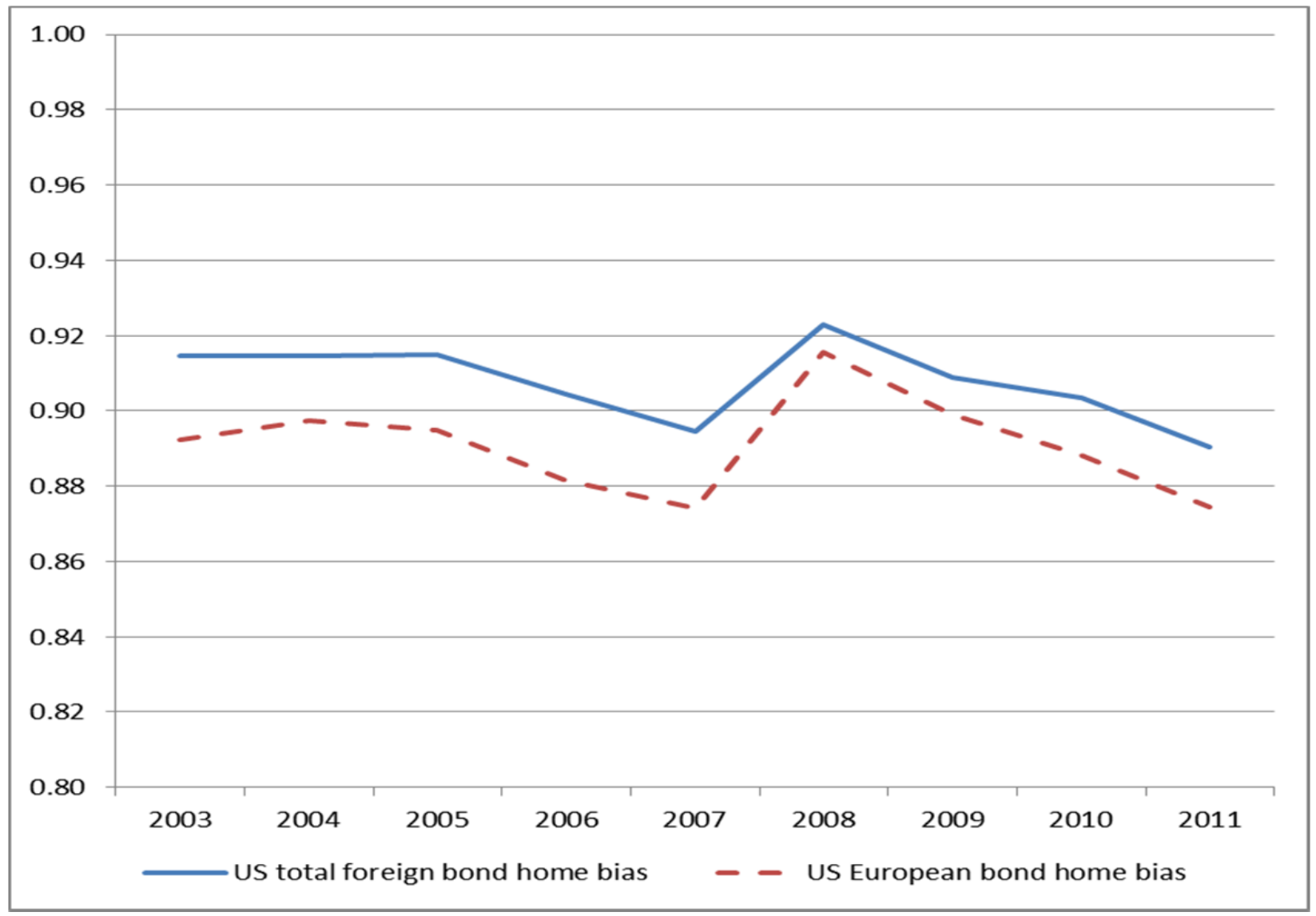


Figure 3. Home Bias in U.S. Holdings of Foreign and European Equity

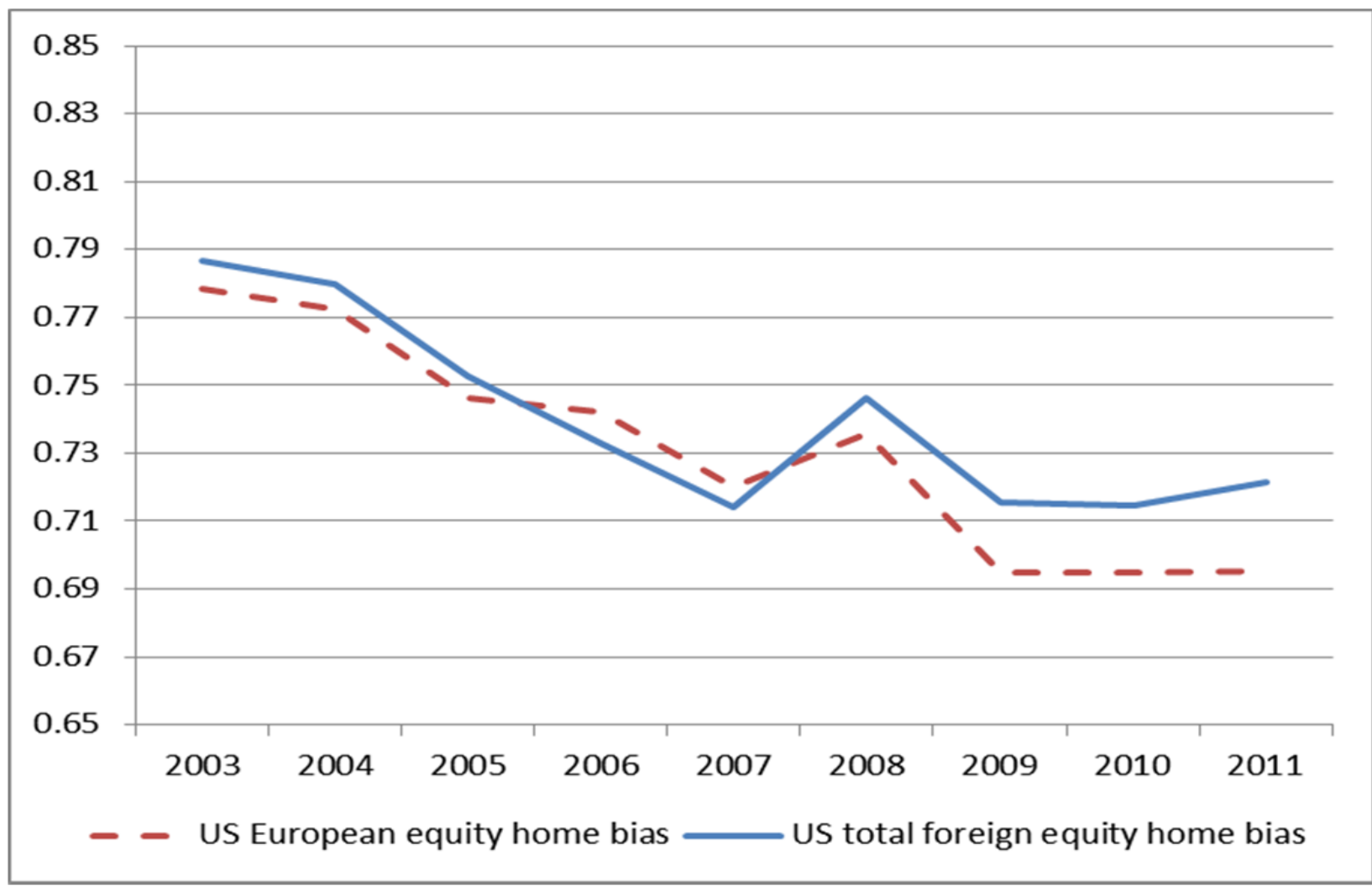


Figure 4. Net investment in European LT debt by Sector (\$ Billion)

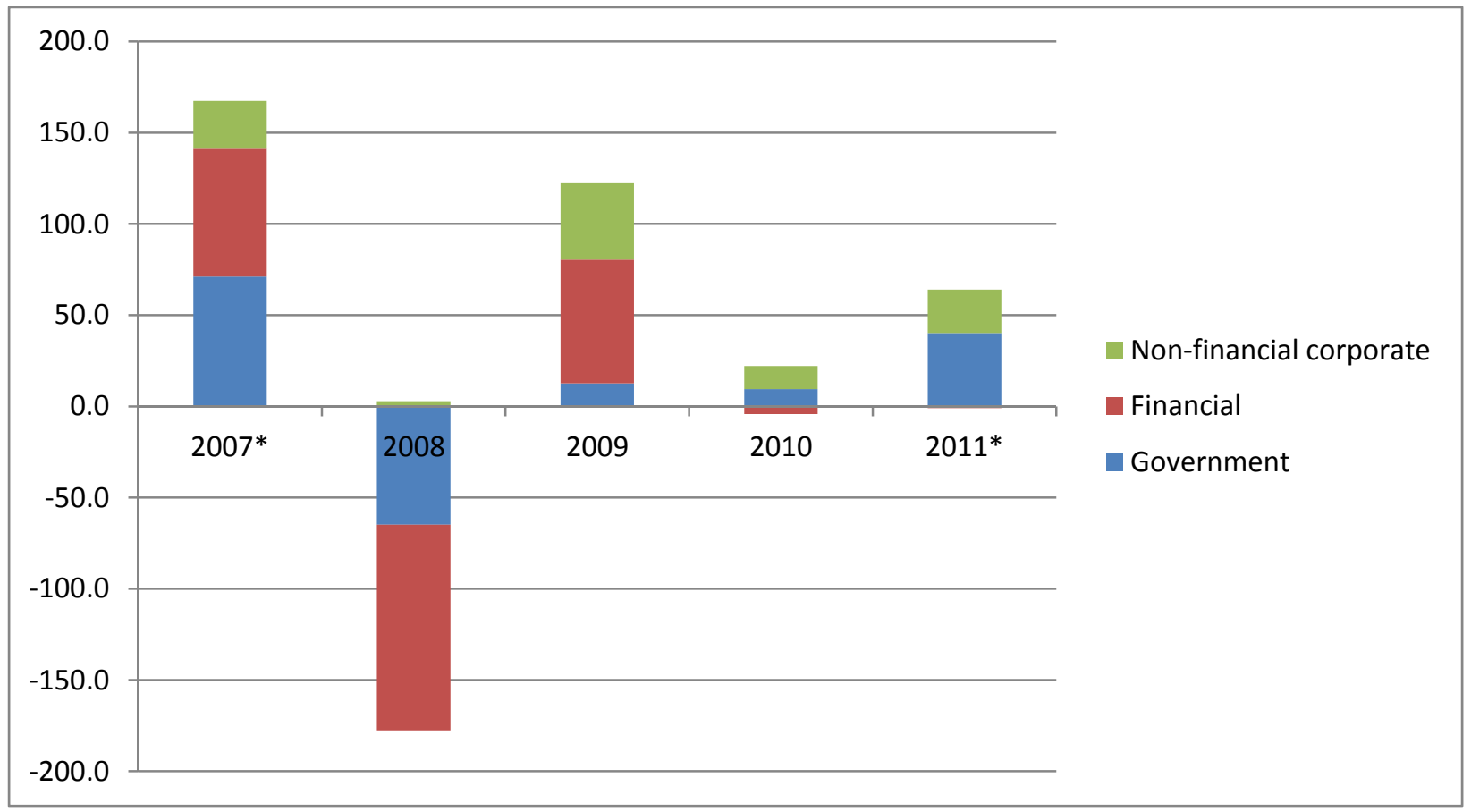

Figure 5. Net Investment in European Government Debt by Region (\$ Billion)

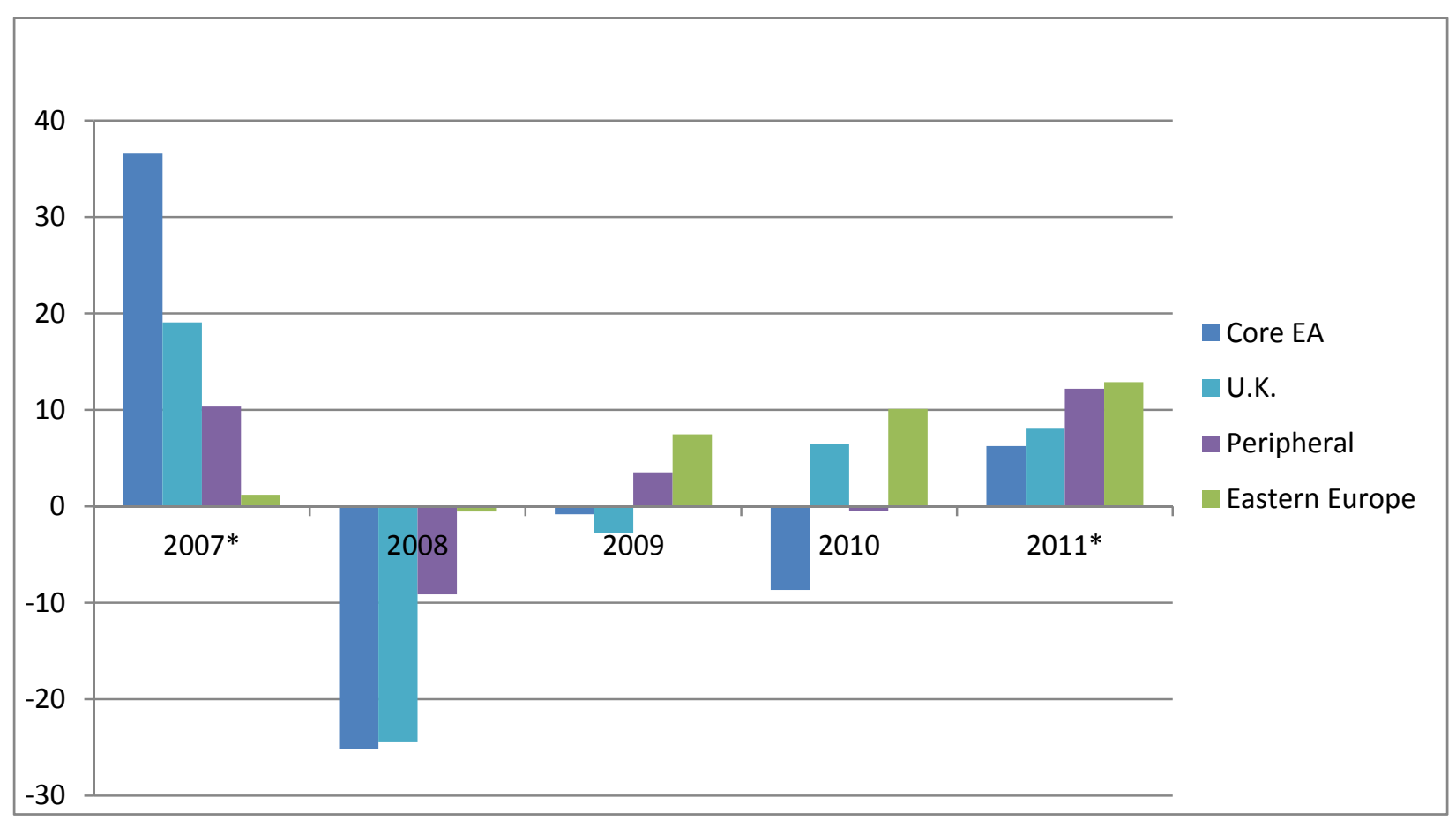

* Adjusted for reporting panel differences for benchmark surveys in 2006 and 2011. 
Figure 6. Net issuances of European Financial Debt (\$ Billion)

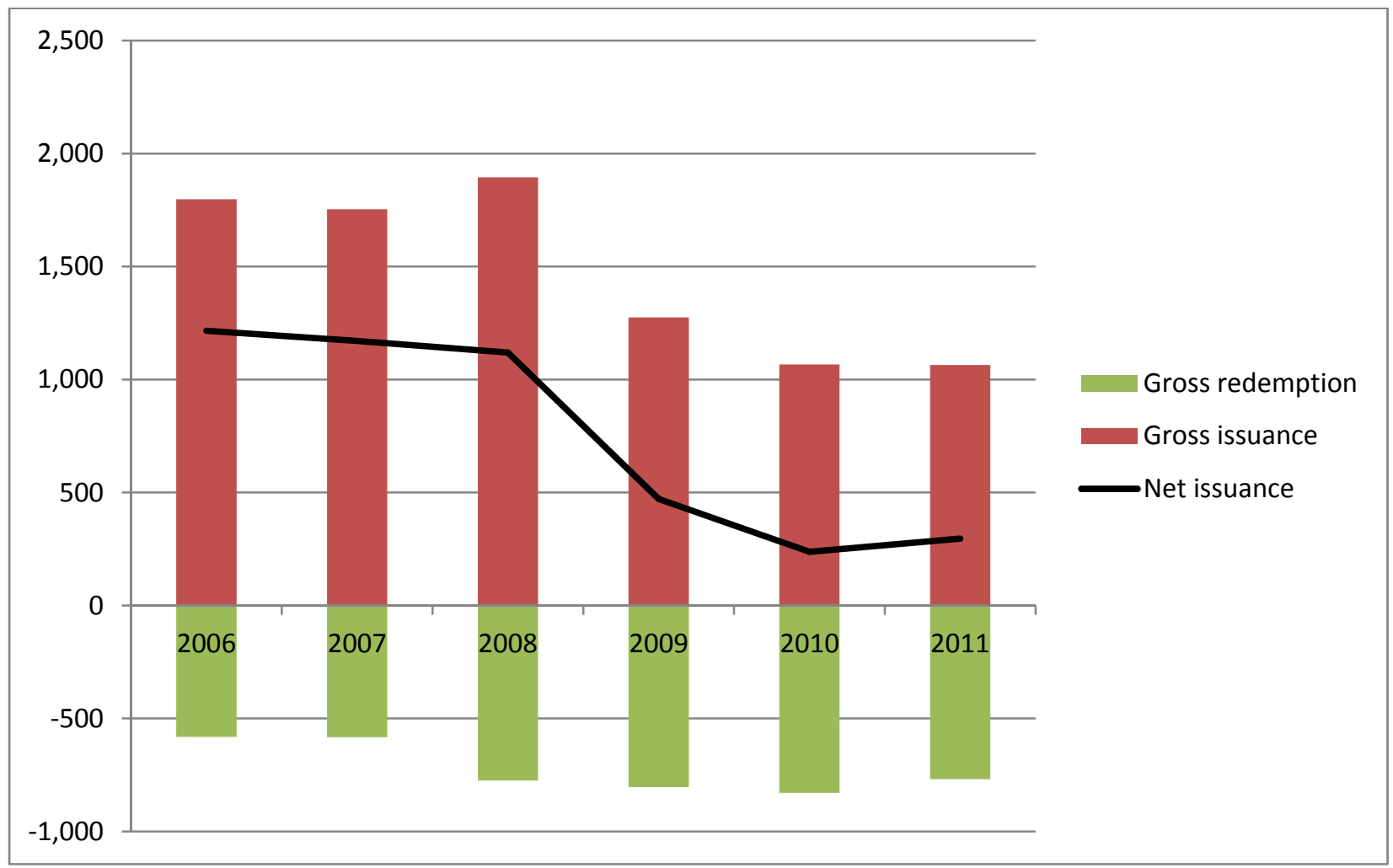




\section{Appendix: Consolidated U.S. Bank Exposure to Europe}

Appendix Table 1 provides estimates of consolidated U.S. bank exposure to Europe from end-2009 through end-2011. Total “exposure” to Europe at end-2011 was about \$1.5 trillion, down somewhat from about $\$ 1.8$ trillion at the start of the euro area crisis. About 80 percent reflects claims on “core” European countries in the euro area, Denmark, Sweden, and the United Kingdom, a share that remained fairly constant over the two-year period. Exposure to peripheral Europe (Greece, Ireland, Italy, Portugal, and Spain) accounted for another 10 percent. Although peripheral exposure declined somewhat in dollar terms over the two-year period (from \$193 billion to $\$ 134$ billion), the biggest change came from reduced exposure to core Europe. Exposure to emerging Europe picked up slightly. 


\section{Appendix Table 1. Exposure of U.S. Banks to Residents of European Countries}

Billions of dollars

\begin{tabular}{l|ccccc}
\hline & Core* & Periphery** & Subtotal*** & $\begin{array}{c}\text { Emerging } \\
\text { Europe }\end{array}$ & Total \\
\hline 2009Q4 & 1,432 & 193 & 1,717 & 56 & 1,773 \\
2010Q1 & 1,448 & 192 & 1,734 & 57 & 1,791 \\
2010Q2 & 1,456 & 153 & 1,705 & 57 & 1,762 \\
2010Q3 & 1,172 & 157 & 1,385 & 65 & 1,450 \\
2010Q4 & 1,119 & 144 & 1,332 & 69 & 1,401 \\
2011Q1 & 1,189 & 169 & 1,427 & 77 & 1,504 \\
2011Q2 & 1,233 & 174 & 1,473 & 75 & 1,548 \\
2011Q3 & 1,302 & 136 & 1,537 & 72 & 1,609 \\
2011Q4 & 1,192 & 134 & 1,408 & 68 & 1,476 \\
2012Q1 & 1,304 & 132 & 1,525 & 74 & 1,599 \\
\hline
\end{tabular}

*France, Germany, United Kingdom, Austria, Belgium, Denmark, Finland, Luxembourg, Netherlands, and Sweden.

** Greece, Ireland, Italy, Portugal, and Spain.

***Core Europe, Peripheral Europe, Norway, and Switzerland.

$\wedge$ Albania, Belarus, Bosnia and Herzegovina, Bulgaria, Croatia, Czech Republic, Hungary, Latvia, Lithuania, Macedonia, Moldova, Poland, Romania, Russia, Serbia, Montenegro, Turkey, and Ukraine.

Note: Exposure of U.S. banks is the sum (for banks headquartered in the United States) of bank lending and bonds held net of third country guarantees and liquid collateral. 